\title{
Effect of ginger and cinnamon extract mixtures on the growth of intestinal bacteria and intestinal inflammation
}

\author{
Min Ju Kim ${ }^{1} \cdot$ Min Seo Kim ${ }^{1} \cdot$ Sung Tae Kang ${ }^{1} \cdot$ Ji Yeon Kim ${ }^{1}$

\section{생강계피 복합물이 장내 유익균 증식 및 염증조절 기능에 미치는 영향}

김민주 ${ }^{1} \cdot$ 김민서 $^{1} \cdot$ 강성태 $^{1} \cdot$ 김지연 $^{1}$

Received: 16 August 2017 / Accepted: 13 September 2017 / Published Online: 31 December 2017

(C) The Korean Society for Applied Biological Chemistry 2017

\begin{abstract}
We aimed to assess the potential growth-promoting effects of ginger and cinnamon mixtures (GCM) on intestinal bacteria and their anti-inflammatory effects in a cellular model of intestinal inflammation. Bifidobacterium longum, Lactobacillus sp., and Lactobacillus acidophilus served as intestinal bacteria. Further, in the inflammatory co-culture model, Caco-2 cells cocultured with RAW264.7 cells were treated with GCM before the addition of lipopolysaccharide (LPS) to induce inflammation in RAW264.7 cells. Addition of GCM to modified Eggerth Gagnon media at a ginger:cinnamon ratio of 1:5 increased the growth of $B$. longum, Lactobacillus sp., and L. acidophilus compared to that of the control. In a cellular model, compared to LPS-treated groups, GCM-treated groups maintained high transepithelial electrical resistance at ginger:cinnamon ratios of 1:1, 1:3, 1:5, and 1:7 and decreased the tight junction permeability at 3:1, 1:1, 1:3, and 1:5 ratios, similar to that shown by the control groups. In addition, GCM-treated groups showed decreased levels of nitrite at 1:1, 1:5, and 1:7 ginger:cinnamon ratios. Based on these results, it can be concluded that among the various combinations of GCM, the ginger:cinnamon ratio of $1: 5$ is the optimal composite ratio that shows positive effects on the intestinal beneficial bacteria and in
\end{abstract}

Ji Yeon $\operatorname{Kim}(\bowtie)$

E-mail: jiyeonk@seoultech.ac.kr

${ }^{1}$ Department of Food Science and Technology, Seoul National University of Science and Technology 232, Gongneung-ro, Nowon-gu, Seoul 01811, Republic of Korea

This is an Open Access article distributed under the terms of the Creative Commons Attribution Non-Commercial License (http://creativecommons. org/licenses/by-nc/3.0/) which permits unrestricted non-commercial use, distribution, and reproduction in any medium, provided the original work is properly cited. anti-inflammation.

Keywords Anti-inflammation - Cinnamon - Extract mixtures · Ginger · Intestinal bacteria

\section{서 론}

인체의 장내에 존재하는 100 조의 세균들은 섭취된 음식물과 소 화관으로부터 분리되는 생체성분을 이용하여 증식하고 분변으 로 배출된다(Park 등, 2010). 장내 세균총들은 장관 내에 증식 함으로서 상호공생관계에 의해 세균총의 균형을 정상적으로 유 지하거나 길항 관계에 의하여 유해 미생물의 증식을 억제하고 있다(Fuller 1992). 장내 미생물들 이외에 장세포들 또한 염증과 관련된 유전자의 발현을 조절하는 다양한 세포 내 신호전달경 로의 활성화를 통해 여러 염증 신호에 반응한다(Beatrice 등, 2009; Romier-Crouzet 등, 2009; Wullaert 등, 2011; Olejnik 등, 2016). 장관 내에서의 염증반응은 tight junction (TJ)을 붕 괴시켜 장누수증후군(leaky gut syndrome)을 초래한다. 항염증 활성을 가지는 플라보노이드 및 페놀 화합물과 같은 식이성분 이 염증성 사이토카인에 의해 유도된 $\mathrm{TJ}$ 손상을 예방한다는 많 은 연구가 보고되고 있다(Ji 등, 2006; Jeong 등, 2011; Suzuki 와 Hara 2011; Ulluwishewa 등, 2011; Kim 2016).

생강(Ginger)은 생강과(Zingiber officinale Roscoe)에 속하는 다년생 초본식물로 특유의 매운맛과 방향성 향기를 지니고 있 어 전 세계적으로 널리 애용되고 있으며, 우리나라에서도 식품 과 음료 등에 많이 사용되고 있는 향신료 중의 하나이다 $(\mathrm{Kim}$ 과 Ahn 1993; Sung 2010). 생강추출물에 관한 연구로 Yang 등(1992)이 생강추출물의 항위염 - 항궤양 작용을 입증하였고, 생강의 항균성에 관하여 식중독 세균에 대한 증식저해작용 연 
구 $(\mathrm{Kim}$ 등, 2000) 및 천연 생강 추출물의 약리학적 특성 및 분 석 연구(Sung 2010) 등이 보고되고 있고, 이들의 약리효과에 대 한 성분들이 밝혀지면서 기능성식품으로의 이용도가 높아지고 있다(Han 2012). 계피(Cinnamomum japonicum SIEB)는 녹나 무과(Lauraceae)에 속하고 Cinnamomum속인 열대성 상록수의 외피를 제거하여 건조하거나 껍질을 그대로 건조시킨 것이며, 인류가 이용한 가장 오래된 항신료 중의 하나이다. 계피의 약 리효능으로는 항균작용 및 항궤양효과(Jeong 등, 1998), 항산화 작용(Park과 Park 2000), 항알레르기 효과(Park 등, 2001), B형 간염 바이러스 억제 효과(Kang 등, 1999) 등이 보고된 바 있다.

생강 에탄올 추출물은 이전 연구에서 장세포의 염증을 조절 하는 효과가 확인된 바 있으며, 계피추출물은 유익균을 선택적 으로 증식시키는 활성이 연구된 바 있다 $(\mathrm{Kim} 2016$; Kim과 $\operatorname{Kim}$ 2016). 따라서 본 연구에서는 장세포의 염증을 조절하는 생강 추출물과 계피 추출물을 혼합하여 장세포의 염증 억제 활 성의 상승효과 및 유익균을 선택적으로 증식시키는 활성을 확 인하고자 한다. 동시에 장 건강에 도움이 되는 복합물의 개발 을 통해 건강기능식품으로의 산업적인 적용 가능성 여부에 대 한 과학적 기초자료를 얻고자 한다.

\section{재료 및 방법}

\section{실험재료}

본 실험에 사용한 계피와 생강 원료는 경기도 성남시 소재 농 협매장에서 구입하여 계피는 10,40 메쉬 및 편상(가로 $2 \times$ 세로 $10 \times$ 두께 $0.2 \mathrm{~cm}$ )으로 전처리 분쇄하여 사용하였으며, 생강은 건 조생강 $($ 가로 $2 \times$ 세로 $1.5 \times$ 두께 $0.2 \mathrm{~cm}$ )을 세절하여 사용하였다.

\section{생강계피 복합물 제조}

생강추출물은 분쇄된 생강의 일정량 시료에 $35 \%$ 에탄올을 가 한 후, $50{ }^{\circ} \mathrm{C}$ 에서 50 분 동안 추출하여 제조하였다. 계피 아임 계 추출은 아임계추출장치(TFS-3000, Innoway Co., Anyang, Korea)를 이용하여 Table 1에 나타낸 아임계 추출 조건으로 추 출하였다. 생강과 계피추출물은 각각 원심분리 $(11,000 \times \mathrm{g}, 5 \mathrm{~min}$, $4{ }^{\circ} \mathrm{C}$ )한 후 여과지(Watman No.4, Maidstone, England)로 여과 한 후 얻은 상등액을 동결 건조하여 분석 시료로 사용하였다. 생강계피 복합물은 $1 \mathrm{mg} / \mathrm{mL}$ 생강추출물 및 계피 추출물을 증 류수에 녹여 만든 후 생강 : 계피의 비율을 $10: 0,7: 1,5: 1$, $3: 1,1: 1,1: 3,1: 5,1: 7,0: 10$ 으로 하였다.

Table 1 Subcritical extraction conditions of cinnamon

\begin{tabular}{lc}
\hline \multicolumn{1}{c}{ Extraction method } & Conditions \\
\hline Solvent & Water \\
Sample & $30 \mathrm{~g}$ \\
Solvent volume & $300 \mathrm{~mL}$ \\
Extraction time & $40 \mathrm{~min}$ \\
Extraction temperature & 110 \\
Stirring speed & - \\
Pressure & $50 \mathrm{bar}$ \\
\hline
\end{tabular}

\section{사용균주 배양}

본 실험에서는 장내 유익균의 지표로 Bifidobacterium longum KCCM11953, Lactobacillus sp. KCCM32821, Lactobacillus acidophilus KCCM32820를 사용하였다. B. longum는 Reinforced Clostridial Media (RCM, Difco, Sparks, NV, USA)배지를 이 용하였고, Lactobacillus sp.와 L. acidophilus::는 MRS broth (Difco, Sparks, NV, USA)에 접종하여 $37{ }^{\circ} \mathrm{C}$ 혐기적 조건(BBL GasPak, Becton Dickinson and Company, Sparks, MD, USA) 으로 활성화시켜 사용하였다.

\section{장내 세균의 생육 활성 측정}

생강계피 복합물이 장내 세균의 생육에 미치는 영향을 조사하 기 위해 Modified EG (Eggerth Gagnon) (Mitsuoka 1980) 액 체배지(Table 2)를 사용하였다. 생강추출물을 동결건조시켜 만 든 추출물을 $0.1,1,10 \mathrm{mg} / \mathrm{mL}$ 농도로 첨가한 Modified $\mathrm{EG}$ broth에 활성화 시킨 각 균의 전배양액을 접종하여 혐기적으로 $37{ }^{\circ} \mathrm{C}$ 에서 24시간 배양한 후 $600 \mathrm{~nm}$ 에서 O.D. (optical density)을 측정하였다.

\section{세포 배양}

본 연구에서 사용한 사람의 장상피세포인 Caco-2 세포와 마우 스의 대식세포인 RAW 264.7 세포는 한국세포주은행(KCLB, Seoul, Korea)에서 구입하였다. Caco-2 세포는 $1 \%$ nonessential amino acid (MEM-NEAA) (Gibco, Rockville, MD, USA), $100 \mathrm{U} / \mathrm{mL}$ penicillin- $100 \mathrm{mg} / \mathrm{mL}$ streptomycin (Gibco, Rockville, MD, USA)과 10\% fetal bovine serum (FBS) (Biowest, Nuaillé, Cholet, France)가 함유된 Dulbecco's modified Eagle's medium (DMEM) (Biowest, Nuaillé, Cholet, France) 배지를 사용하였고, RAW 264.7 세포는 $10 \% \mathrm{FBS}, 1 \% \mathrm{HEPES}$ (1 M) (Gibco, Rockville, MD, USA)와 $100 \mathrm{U} / \mathrm{mL}$ penicillin$100 \mathrm{mg} / \mathrm{mL}$ streptomycin가 함유된 DMEM 배지를 사용하였다. 세포는 $5 \% \mathrm{CO}$ 및 $37^{\circ} \mathrm{C}$ 가 유지되는 배양기에서 계대배양하 였다.

\section{Co-culture system}

연구를 위해 Caco-2 세포를 6-transwell의 상층부 (apical side) $(0.4 \mu \mathrm{m}$ pore size; Corning Costar Corp., USA)에 $1 \times 10$ cells/well의 농도로 seeding 하였다. 세포 배지는 2-3일에 한번

Table 2 The composition of modified EG broth

\begin{tabular}{lc}
\hline \hline \multicolumn{1}{c}{ Components } & Amount \\
\hline Beef extract & $2.0 \mathrm{~g}$ \\
Proteose peptone No.3 & $10.0 \mathrm{~g}$ \\
Yeast extract & $5.0 \mathrm{~g}$ \\
Na2HPO4 & $4.0 \mathrm{~g}$ \\
Soluble starch & $0.5 \mathrm{~g}$ \\
Glucose & $1.5 \mathrm{~g}$ \\
L-cysteine & $0.4 \mathrm{~g}$ \\
Silicon antifoamer & $0.25 \mathrm{~mL}$ \\
Tween 80 & $0.5 \mathrm{~g}$ \\
D.W. & $1,000 \mathrm{~mL}$ \\
\hline
\end{tabular}


씩 교체했으며, 21일 동안 배양하였다. RAW 264.7 세포는 transwell의 하층부 (basolateral side)에 $1 \times 10$ cells/well의 농도 로 seeding 하였고, 48시간 배양하였다. 48시간 후, co-culture에 서 시료의 항염증 효과를 확인하기 위해 다양한 비율의 복합물 을 transwell 상층부에 처리하였다. 처리된 농도는 3-(4,5dimethyl-2-thiazolyl)-2,5-diphenyl-2H-tetrazolium bromide assay 를 통해 결정하였다 (Lee 등, 2017). 24시간 후, $2 \mu \mathrm{g} / \mathrm{mL}$ lipopolysaccharide (LPS) (Sigma-Aldrich, St. Louis, MO, $\mathrm{USA}$ )를 transwell 하층부에 처리하고 48 시간 동안 $37^{\circ} \mathrm{C}$ 에서 방 치하였다.

\section{Transepithelial electrical resistance (TEER) 측정}

생강계피 복합물을 transwell 상층부에 처리하여 24시간 배양한 후 LPS를 하층부에 첨가하였다. Millicell ${ }^{\mathbb{R}}$ ERS instrument (Millipore, Bedford, MA, USA)을 이용하여 LPS를 처리하기 전에 0 시간, 처리한 후로부터 $0.5,1,3,6,12,24,48$ 시간 때 TEER을 측정하였다. 복합물과 LPS 처리에 따른 상층부와 하 층부 간의 TEER 값은 3 반복으로 행해졌으며, $\Omega$ (resistance)× $\mathrm{cm}^{2}$ (surface area of the monolayer)로 계산되었다.

\section{Permeability 측정}

Transepithelial permeability는 Fluorescein isothiocyanate (FITC)-
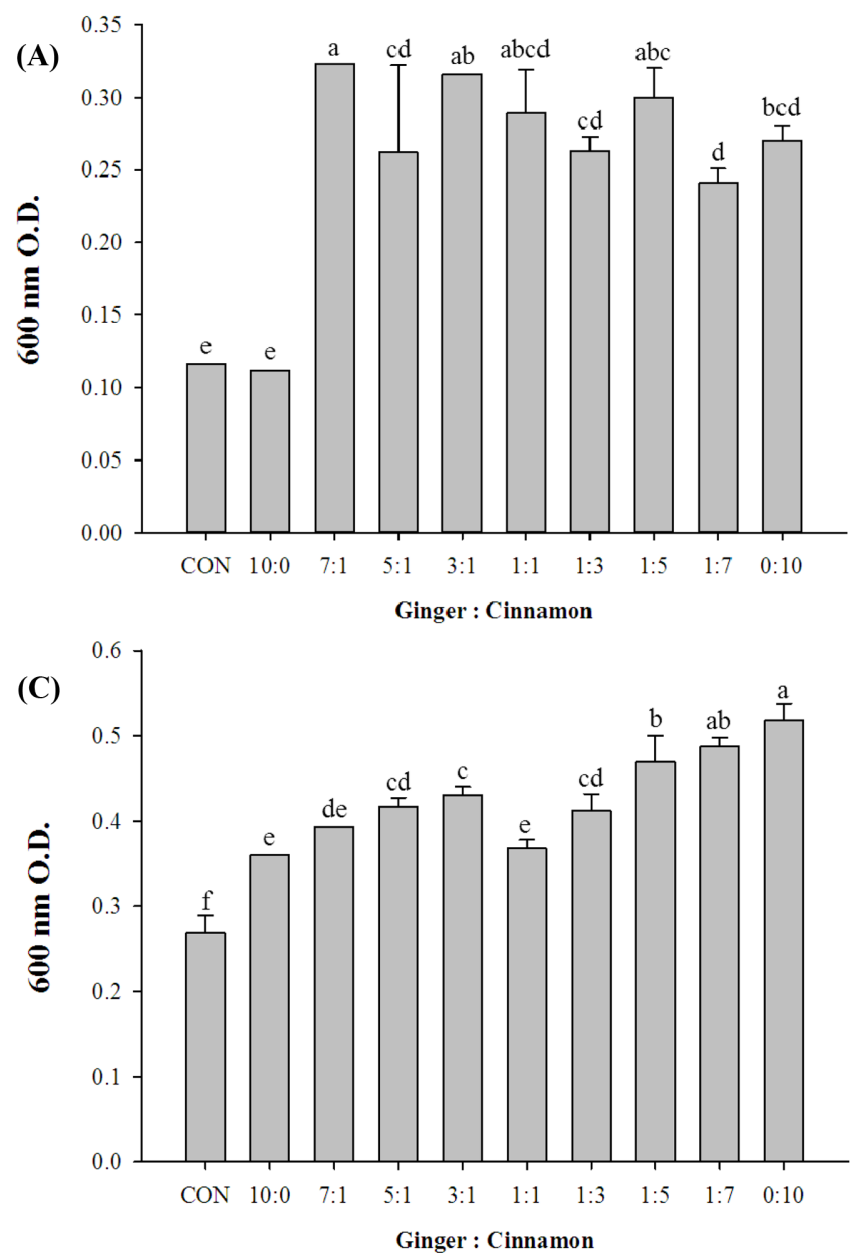

labeled dextran (FITC-dextran; $4 \mathrm{kDa}$ ) (Sigma-Aldrich, St. Louis, $\mathrm{MO}, \mathrm{USA})$ 의 세포 투과성을 측정하여 확인하였다. 상층부에서 Caco-2 세포를 통과한 FITC-dextran $(100 \mu \mathrm{g} / \mathrm{mL})$ 의 형광도를 하층부에서 측정하였다. 즉, FITC-dextran을 상층부에 첨가하고 48시간 후, 하층부의 배지를 $300 \mu \mathrm{L}$ 씩 새로운 96 well plate에 옮겨 fluorescence spectrophotometer (PerkinElmer, Waltham, MA, USA)를 이용하여 excitation wavelength $485 \mathrm{~nm}$ 와 emission wavelength $535 \mathrm{~nm}$ 에서 형광도를 측정하였다.

\section{Nitrite 생성량 측정}

Caco-2 세포 배양액 내의 nitrite 함량 측정은 Griess 반응을 이 용하여 실시하였다. 상층액을 모아 $11,000 \mathrm{~g}$ 에서 10 분간 원심분 리한 후, 상층액 $100 \mu \mathrm{L}$ 와 Griess reagent $100 \mu \mathrm{L}$ 를 혼합하였다. 빛을 차단하여 10 분간 방치하였다. 흡광도는 microplate reader (BioTek, Winooski, VT, USA)를 사용하여 $540 \mathrm{~nm}$ 에서 측정되 었으며, sodium nitrite를 이용하여 표준곡선을 작성하여 함량을 계산하였다. Griess reagent는 5\% phosphoric acid와 $1 \%$ sulfanilamide를 혼합한 후, $0.1 \% \quad \mathrm{~N}$-(1-naphthyl)ethylenediamine) dihydrochloride 용액을 동량으로 혼합하여 사용하였다. 양성대 조군으로 butein $(10 \mu \mathrm{M})$ (Sigma-Aldrich, St. Louis, MO, USA) 을 사용하였다(Jung 등, 2017).

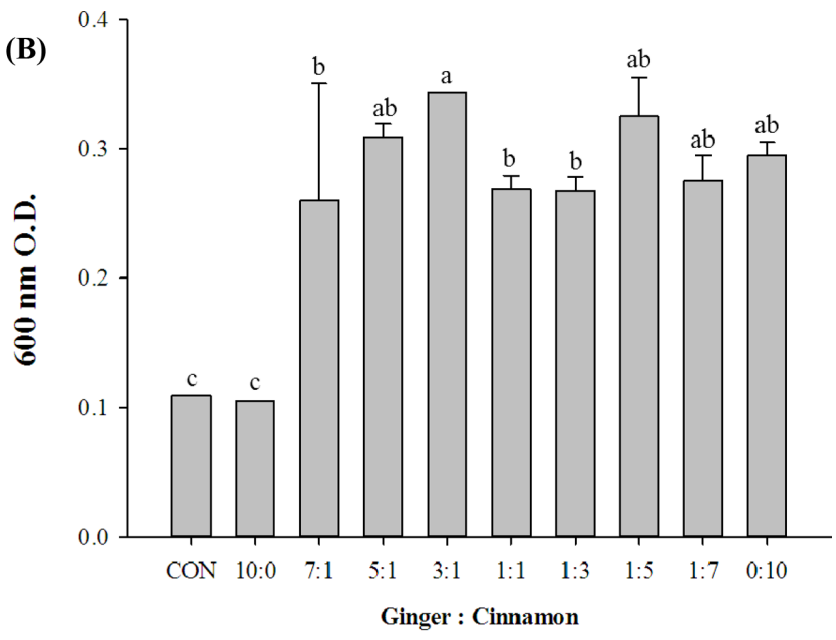

Fig. 1 Effects of Ginger and Cinnamon extract mixtures on growth of intestinal bacteria by modifed EG broth. (A) Bifidobacterium longum, (B) Lactobacillus sp., (C) Lactobacillus acidophilus, Different letters above the bars indicate significant differences (Duncan's multiple range test; $p$ $<0.05$ ) 


\section{통계처리}

측정된 결과는 SPSS program (20.0, SPSS Inc., Chicago, IL, USA)을 이용하여 일원배치분산분석을 실시한 후 유의적 차이 가 있는 경우 다중비교분석법인 Duncan's multiple range test one-way ANOVA를 활용하여 유의수준 $p<0.05$ 에서 비교하였다.

\section{결과 및 고찰}

\section{생강계피 복합물에 따른 장내 세균의 생육 활성}

생강계피 복합물에 대한 장내 세균의 활성 효과를 측정하기 위 해 Modified EG 액체배지에 생강계피 복합물을 비율별로 처리 한 결과를 Fig. 1에 나타내었다. 장내 유익균인 B. longum와 Lactobacillus sp.는 모든 생강계피복합물과 계피추출물에서 대 조군과 유의적인 차이를 나타내었고, 유익균인 L. acidophilus는 생강추출물, 모든 생강계피복합물 및 계피추출물에서 대조군과 유의적인 차이가 나타났다 $(p<0.05)$. 생강계피 복합물의 생강:계 피 비율을 $10: 0$ 으로 처리한 결과, 장내 유익균인 B. longum, Lactobacillus sp. 균주의 생육이 감소하는 경향을 나타냈고 유익 균인 L. acidophilus 의 생육은 유의적으로 증가하였다 $(p<0.05)$. B. longum은 생강 : 계피 $7: 1,3: 1,1: 1$ 및 $1: 5$ 복합물에서 최대 생육 활성이 나타났고, Lactobacillus sp.는 생강:계피 $5: 1$,
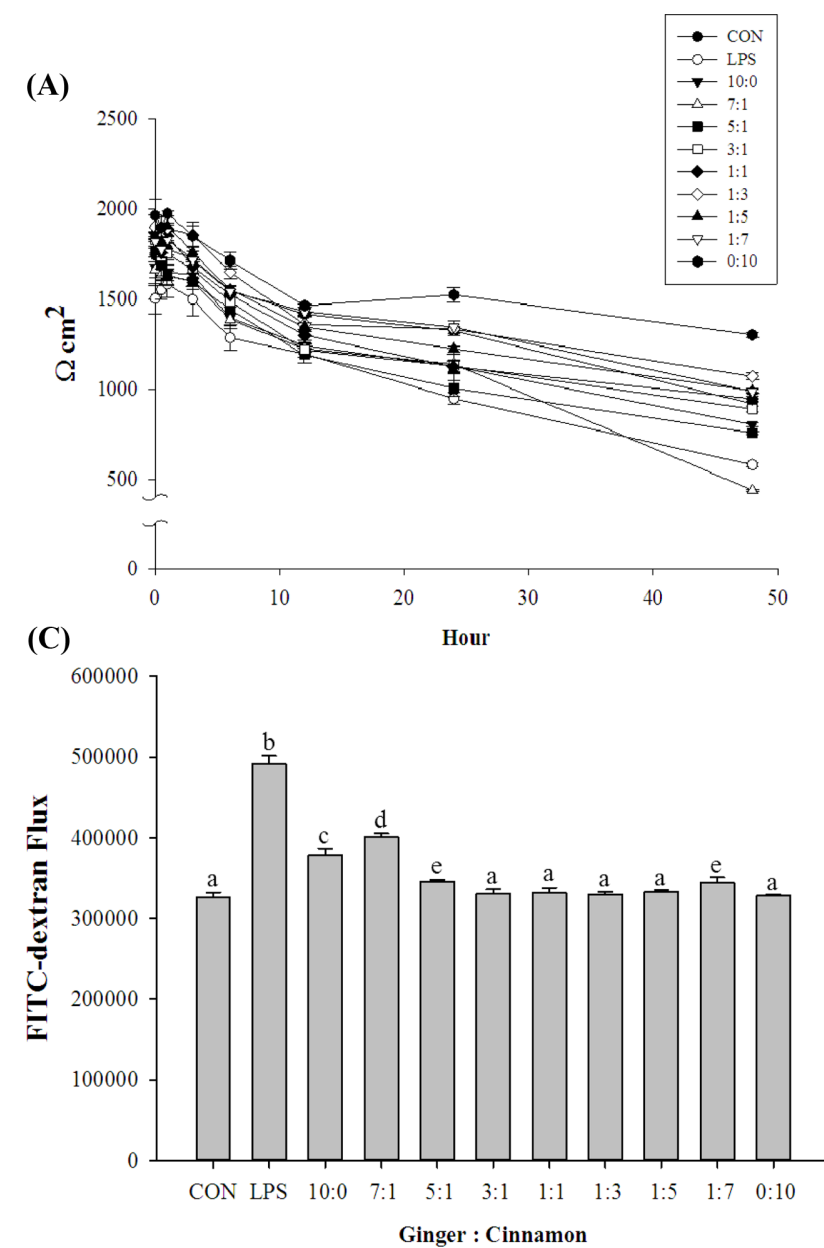

$3: 1,1: 5,1: 7$ 및 $0: 10$ 복합물에서 가장 높은 생육 활성을 보였으며, L. acidophilus는 생강 : 계피 $1: 5,1: 7$ 및 $0: 10$ 복 합물에서 최대 생장을 하였다. 녹차의 메탄올 추출물(Ahn $\mathrm{YJ}$ 등, 1990b), 쑥의 물 분획물(Lee와 Shin 1995) 및 인삼의 물추 출물과 메탄올추출(Ahn YJ 등, 1990a)의 연구에서는 Bifidobacterium sp.의 생육을 촉진시키고 장내 미생물 균총의 생육에 영향을 끼친다고 보고하였다. 본 연구에서 생강계피 복합물은 장내 유익균인 B. longum, Lactobacillus sp.와 L. acidophillus 균주의 생육을 촉진시켰고 특히, $1: 5$ 복합물이 세 가지 장내 유 익균의 생육을 모두 최대로 상승 시키는 것으로 관찰되었다.

\section{Tight junction (TJ) permeability 확인}

생강계피 복합물이 LPS에 의한 Caco-2 세포의 TEER 감소를 억 제할 수 있는지 확인하였다. TEER 측정 결과로, LPS 처리에 의 해 세포의 TEER 값이 유의적으로 감소한다는 것을 확인하였다 (Fig. 2). 48시간이 경과하였을 때 LPS 처리군에서 TEER 값이 약 $60 \%$ 정도 감소하였고, 대조군에 비해 TEER 값을 약 $16 \%$ 정도 더 감소시켰다(Fig. 2B). LPS 처리가 Caco-2 세포의 tight junction을 손상시킨다는 것을 확인할 수 있었다. 반면에, 생강계 피 복합물 전처리는 LPS로 감소된 TEER 값의 감소를 억제하였 다. 생강 : 계피 $1: 1,1: 3,1: 5,1: 7$ 복합물은 대조군보다도 $\mathrm{TEER}$ 값이 증가하였으며, 생강 : 계피 $1: 3$ 복합물이 가장 좋은

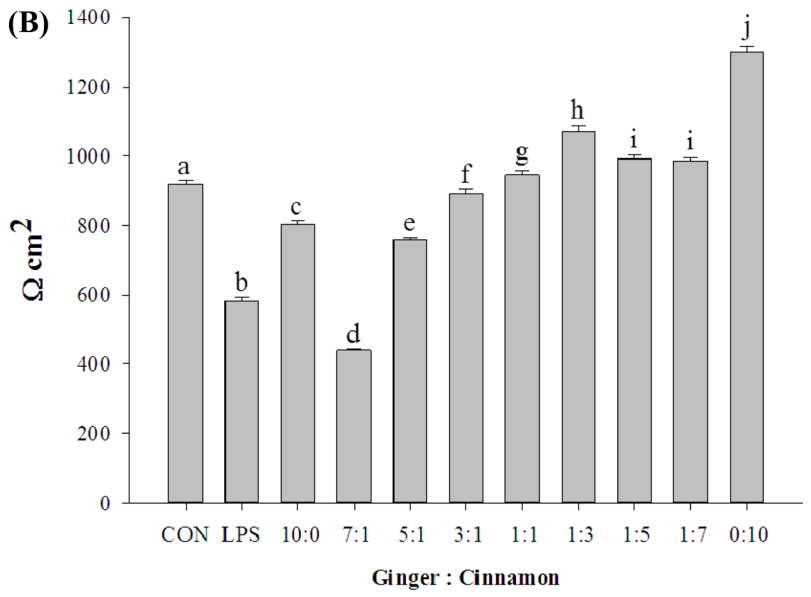

Fig. 2 (A) Time course of transepithelial electrical resistance (TEER) value, (B) protective effects of ginger and cinnamon extract mixtures on TEER value at $48 \mathrm{~h}$, and (C) FITC-dextran flux. Caco-2 cells were seeded in 6-transwell insert plate at a density of $1.0 \times 10^{5}$ cells $/ \mathrm{mL}$ and incubated with RAW264.7 cells before ginger and cinnamon extract mixtures were added to the apical side of the co-culture system. Then, LPS $(2 \mu \mathrm{g} / \mathrm{mL})$ was treated to the basolateral side and incubated for $48 \mathrm{~h}$. Different letters above the bars indicate significant differences (Duncan's multiple range test; $p<0.05$ ). CON, control; LPS, lipopolysaccharide 
효과를 나타냈다(Fig. 2B). FITC-dextran은 paracellular transport path를 통해 Caco-2 세포 단층의 상층부에서 하층부로 이동함으 로써 투과성이 높을수록 $\mathrm{TJ}$ 이 느슨한 것으로 판단할 수 있다 (Kim 2016). 생강계피 복합물이 TJ를 통한 FITC-dextran의 이동 에 미치는 영향을 확인하기 위해 FITC-dextran을 처리하고 48시 간 후에 관찰하였다. Fig. 2 C에서 보이는 바와 같이 LPS 처리군 에서 FITC-dextran flux가 약 1.5 배 증가되었다. 그러나 생강계피 복합물 처리군에서 LPS 처리로 인한 FITC-dextran flux가 감소 되었다. 생강 : 계피 $3: 1,1: 1,1: 3,1: 5$ 복합물은 대조군과 유 사한 결과를 보였다 (Fig. 2C). 박테리아 유래 LPS는 장 상피 $\mathrm{TJ}$ 를 통해 항원의 흡수를 증가시키고 leak-flux diarrhea를 유발 하여 장벽 기능을 손상시키는 것으로 보고되었다(Wu 등, 2014). 많은 천연물질들이 Caco-2의 TJ를 강화시킨다는 연구들이 보고 되고 있으며(Lee 등, 2011; Lee 등, 2015; Kim 2016), 이번 연 구에서도 LPS가 TJ를 손상시키지만 생강과 계피 복합물이 TJ 손상을 억제하고 강화시킨다는 것을 확인할 수 있었다. 따라서 본 결과를 통해 생강 : 계피 $1: 1,1: 3,1: 5$ 복합물은 장세포의 결합을 유지하는데 도움을 줄 수 있다고 판단할 수 있다.

\section{Nitrite 생성량 확인}

$\mathrm{NO}$ 는 체내 방어기능, 신호전달, 혈관확장 등의 다양한 생리기능 을 가지고 있어 중요한 역할을 하나 $\mathrm{NO}$ 가 정상 이상으로 상승 되어 산소와 결합한 peroxynitrite (ONOO-)가 생성되면 조직의 염증을 유발시키게 되며, 손상, 유전자 변이 및 신경 손상을 주 게 된다(Cho 2011; Kim 등, 2015). Co-culture 에서 생강계피 복합물이 LPS로 유도된 NO 생성량에 영향을 미치는지 알아보 기 위해, $2 \mu \mathrm{g} / \mathrm{mL}$ 의 LPS 처리 후, $\mathrm{NO}$ 를 상층부의 세포 상층액 에서 측정하였다. LPS 처리군은 대조군에 비하여 $\mathrm{NO}$ 를 약 40 배 정도 증가시켰다(Fig. 3). 반면에, 생강계피 복합물 처리군은 LPS로 유도된NO 생성량을 감소시켰으며, 여러 복합물 중 생 강 : 계피 $1: 1,1: 5$ 와 $1: 7$ 복합물이 약 2 배씩 감소시켜 가장 좋은 효과를 나타냈다. 양성대조군으로 사용된 butein은 항암 $(\mathrm{Li}$ 등, 2008; Pandey 등, 2009) 및 항염증(Zhang 등, 2008) 효과를 나타낸다고 알려져 있는 물질로 LPS로 유도된 NO 생성량을 4 배 감소시켰다. 면역 세포의 활성과 염증 사이토카인의 증가는 $\mathrm{IBD}$ 에서 일반적으로 관찰된다(Kim 등, 2015). 염증이 유발되면 inducible nitric oxide synthase (iNOS)는 과도한 $\mathrm{NO}$ 생성을 촉 진시킨다(Aktan 2004). Kim 등(2017)은 생강추출물과 지표성분 인 6-gingerol 및 6-shogaol이 염증 사이토카인으로 처리된 Caco2 의 염증반응을 감소시키고 $\mathrm{TJ}$ 를 강화시킨다고 보고하였다. 그 리고 계피의 지표성분인 cinnamaldehyde, cinnamic alcohol 및 cinnamic acid는 LPS로 유도된 대식세포와 마우스 모델에서 염 증 반응을 억제시킨다고 보고되었다(Lee 2009; Liao 등, 2012). 본 연구에서는 생강 : 계피 $1: 1,1: 5,1: 7$ 복합물이 LPS로 유 도된 $\mathrm{NO}$ 생성을 억제하였다. 생강과 계피 복합물의 장에서의 염 증 억제와 관련된 기전에 대해서는 추가적으로 연구가 필요할 것이다.

\section{초 록}

본 연구에서 생강과 계피 추출물 및 복합물의 장내 개선 효능을

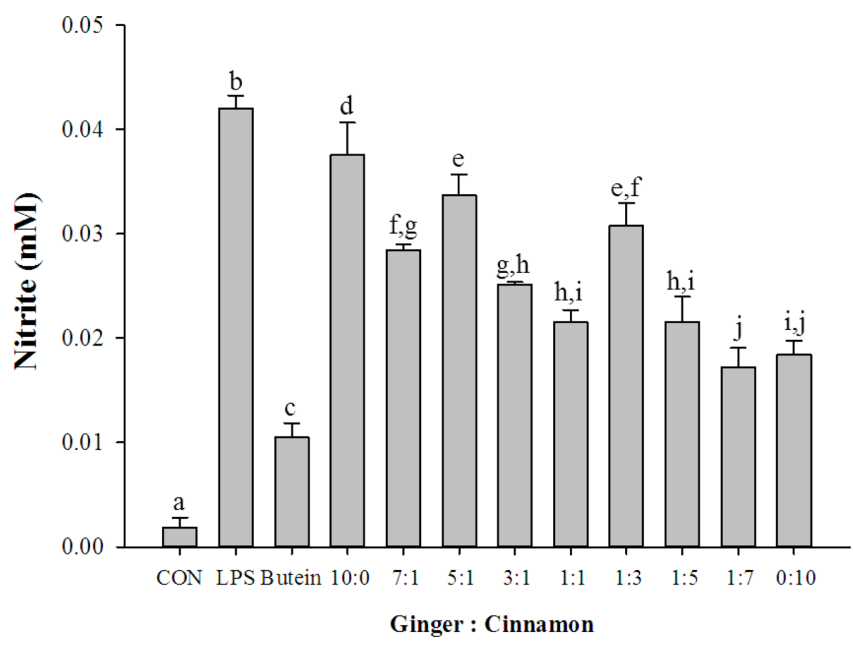

Fig. 3 Concentration profile of Nitrite. Caco-2 cells were seeded in 6transwell insert plate at a density of $1.0 \times 10^{5}$ cells $/ \mathrm{mL}$ and incubated with RAW264.7 cells before ginger and cinnamon extract mixtures were added to the apical wells of co-culture system. Then, LPS $(2 \mu \mathrm{g} / \mathrm{mL})$ was treated to the basolateral side and incubated for $48 \mathrm{~h}$. The levels of Nitrite was analyzed from the collected culture supernatants using Griess reagent assay. Butein $(10 \mu \mathrm{M})$ was used as a positive control. Different letters above the bars indicate significant differences (Duncan's multiple range test; $p<0.05)$. CON, control; LPS, lipopolysaccharide

조사하였다. 생강계피 복합물을 Modified EG 액체배지에 처리하 고 대표적인 유익균인 B. longum, Lactobacillus sp.와 L. acidophilus 균주를 접종하여 생육 활성을 관찰하였다. 그리고 사 람의 장상피세포인 Caco-2 cell과 마우스의 대식세포인 RAW 264.7을 co-culture한 model에서 생강계피 복합물을 처리한 후 lipopolysaccharide (LPS)로 자극시켜 Transepithelial electrical resistance (TEER), permeability 그리고 nitrite 생성량을 확인하였 다. 그 결과, 생강계피 복합물을 생강 : 계피 $1: 5$ 로 처리 시, $B$. longum, Lactobacillus sp. 및 L. acidophilus 세 가지 균주의 성 장을 모두 최대로 상승시켜 생육 활성 효과가 우수하였다. 특히 생강계피 복합물은 대조군에 비해 Lactobacillus sp. 균주의 가장 높은 생육 상승을 나타내어 생강계피 복합물에 젖산균의 생육인 자를 함유할 것으로 추정된다. 반면 장 염증활성 조절을 확인하 기 위한 co-culture model에서는, LPS 처리군과 비교하여, 생강 계피 복합물 처리군 중 생강 : 계피 $1: 1,1: 3,1: 5$ 와 $1: 7$ 복합 물이 대조군과 비슷하거나 더 높게 증가하였고, tight junction (TJ) permeability는 생강 : 계피 $3: 1,1: 1,1: 3$ 과 $1: 5$ 복합물 에서 대조군과 비슷하게 감소하였다. 또한, 생강: 계피 $1: 1,1: 5$ 와 $1: 7$ 복합물은 nitrite의 수준을 감소시켰다. 장내 유익균의 생 육 및 장 염증 억제 활성 결과를 종합하여 볼 때 생강계피 복 합물 중 생강 : 계피 $1: 5$ 복합물이 장내 유익균과 염증 조절에 좋은 효과를 나타내는 최적 복합비율이라고 판단할 수 있다.

\section{Keywords 계피 - 복합물 - 생강 - 장내 미생물 - 항염증}

감사의 글 본 결과물은 농림축산식품부의 재원으로 농림수산식품기술기획 평가원의 고부가가치식품기술개발사업의 지원을 받아 연구되었습니다(과제 번호: 116012-3). 


\section{References}

Ahn YJ, Kim MJ, Kawamura T, Yamamoto T, Fujisawa T, Mitsuoka T (1990a) Effect of Panax ginseng extract on growth responses of human intestinal bacteria and bacterial metabolism. Korean J Ginseng Sci 14: 253-264

Ahn YJ, Sakanaka S, Kim MJ, Kawamura T, Fujisawa T, Mitsuoka T (1990b) Effect of green tea extract on growth of intestinal bacteria. Microb Ecol Health Disease 3: 335-338

Aktan F (2004) iNOS-mediated nitric oxide production and its regulation. Life Sci 75: 639-653

Cho YJ (2011) Anti-inflammatory Effect of Jatrorrhizine from Phellodendron amurense in Lipopolysaccharide-stimulated Raw264.7 Cells. J Appl Biol Chem 54(2): 114-119

Fuller R (1992) Probiotics. The scientific basis. Chapman and Hall, London

Han EJ (2012) Quality characteristics of muffins containing ginger juice. Korean J Culinary Research, 18(5): 256-266

Jeong ET, Park MY, Lee JG, Chang DS (1998) Antimicrobial activity and antimutagenesis of cinnamon (Cinnamomum cassia Blume) bark extract. J Fd Hyg Safety 13: 337-343

Jeong HM, KIm YS, Ahn SJ, Auh MS, Ahn JB, Kim KY (2011) Effect of Zizyphus jujuba var. boeunesis extracts on the growth of intestinal microflora and its antioxidant activities. J Korean Soc Food Sci Nutr 40(4): 500-508

Ji MS, Park MJ, Lee MY, Kim JG, Ko BS (2006) Effect of Hehotang extrac on the growth of intestinal bacteria and immunostimulation. Korean J. Food Sci technol 38: 104-108

Jung JW, Ko JH, Ko WM, Park JH, Baek YS (2017) Isoprenylated flavonoids from the root bark of Morus alba L. and their inhibition effect on NO production in LPS-induced RAW 264.7 cells. J Appl Biol Chem 60(2): 109-111

Kang SY, Kim TG, Park MS, Han HM, Jung KK, Kang JH, Moon A, Kim SH (1999) Inhibitory effects of Eugenia caryophyllate, Ephedra sinica and Cinnamomum cassia on the replication of HBV in HepG2 2.2.15 cells. J Appl Pharmacology 7: 133-137

Kim CY (2016) Inhibition of Interleukin-1á-induced Intestinal Epithelia Tight Junction Permeability by Curcumin Treatment in Caco-2 Cells. J Life Sci 26: 1082-1087

Kim EJ, Ahn MS (1993) Antioxidative effect of ginger extracts. Korean J Soc Food Sci 9: 37-42

Kim JY, Kim DM (2016) Nutritional composition containing ginger extract for enhancing tight junctions in intestinal cells and prepeparing method thereof. Korea Patent 10-2016-009166, 19 Jul 2016

Kim KM, Kim YS, Lim JY, Min SJ, Ko HC, Kim SJ, Kim Y (2015) Intestinal anti-inflammatory activity of Sasa quelpaertensis leaf extract by suppressing lipopolysaccharide-stimulated inflammatory mediators in intestinal epithelial Caco-2 cells co-cultured with RAW 264.7 macrophage cells. Nutr Res Pract 9: 3-10

Kim L, Kwon O, Kim JY (2015) Comparison of Protective Effects of Young and Ripened Persimmon Extracts against Inflammatory Stress Induced by Deoxycholic Acid in Small Intestinal Cells. J Korean Soc Food Sci Nutr 44(10): 1583-1587

Kim ML, Choi KH, Park CS (2000) Growth inhibition of food-borne bacteria by juice and extract of Ginger and Garlic. J, East Asian Soc. Dietary Life 10: $160-169$

Kim Y, Kim DM, Kim JY (2017) Ginger Extract Suppresses Inflammatory Response and Maintains Barrier Function in Human Colonic Epithelial Caco-2 Cells Exposed to Inflammatory Mediators. J Food Sci 82: 12641270

Lee EH, Cho JH, Kim DH, Hong SH, Kim NH, Park MJ, Hong EJ, Cho YJ
(2017) Anti-inflammatory activity of manassantin A from ultra-fine ground Saururus chinensis in lipopolysaccharide-stimulated RAW 264.7 cells. Appl Biol Chem 60(1): 63-71

Lee HS (2009) Chemical Composition of Cinnamomum cassia Leaf Oils and Suppression Effect of Cinnamyl Alcohol on Nitric Oxide Synthase. Appl Biol Chem 52: 480-485

Lee J, Ko S, Kim H, Kwon H (2011) Integrity and cell-monolayer permeability of chitosan nanoparticles in simulated gastrointestinal fluids. Food Sci Biotechnol 20(4): 1033-1042

Lee MY, Kim H, Shin KS (2015) In vitro and in vivo effects of polysaccharides isolated from Korean persimmon vinegar on intestinal immunity. J Korean Soc Appl Biol Chem 58(6): 867-876

Lee SH, Shin HK (1995) Effect of the fractionated extracts of mugwort on the in vitro growth of some intestinal microorganism. Korean J. Nutr 28: 1065-1072

Li Rui, Chen Wei, Li Xu (2008) A novel anticancer effect of butein: Inhibition of invasion through the ERK $1 / 2$ and NF- $\mathrm{BB}$ signaling pathways in bladder cancer cells. FEBS Letters 582, doi: 10.1016/ j.febslet.2008.04.046

Liao JC, Deng JS, Chiu CS, Hou WC, Huang SS, Shie PH, Huang GJ (2012) Anti-Inflammatory Activities of Cinnamomum cassia Constituents In Vitro and In Vivo. Evid Based Complement Alternat Med 2012:429320

Mitsuoka T (1980) A color atlas of anaerobic bacteria. Sobunsha, Tokyo

Olejnik A, Kowalska K, Kidon M, Czapski J, Rychlik J, Olkowicz M, Dembczynski R (2016) Purple carrot anthocyanins suppress lipopolysaccharide-induced inflammation in the co-culture of intestinal Caco-2 and macrophage RAW264.7 cells. Food Funct 7: 557-564

Pandey MK, Sung B, Ahn KS, Aggarwal BB (2009) Butein Suppresses Constitutive and Inducible Signal Transducer and Activator of Transcription (STAT) 3 Activation and STAT3-Regulated Gene Products through the Induction of a Protein Tyrosine Phosphatase SHP-1. Molecular Pharmacology 75(3): 525-533

Park KH, Koh DS, Lim YH (2001) Anti-allergic compound isolated from Cinnamomum cassia. J Korean Soc Agric Chem Biothechnol 44: 40-42

Park KR, Lee WJ, Cho MG, Park ES, Jeong JY, Kwon OS, Yoon HS, Kim KY (2010) Effects of the extract from Gyrophora esculenta and Coriolus versicolor judae mycelia on the growth of intestinal bactera. J Korean Soc Food Sci Nutr 39(6): 820-825

Park RJ, Park YK (2000) Studies on the effects of the parts of Cinamomum cassia Presl on the antioxidation (I). Kor J Herbology 15: 45-55

Romier-Crouzet B, Van De Walle J, During A, Joly A, Rousseau C, Henry O, Larondelle Y, Schneider YJ (2009) Inhibition of inflammatory mediators by polyphenolic plant extracts in human intestinal Caco-2 cells. Food Chem Toxicol 47: 1221-1230

Sung KC (2010) A study on the pharmaceutical characteristics and analysis of natural ginger extract. J of the Korean Oil Chemists' Soc, 27: 266-272

Suzuki T, Hara H (2011) Role of flavonoids in intestinal tight junction regulation. J Nutr Biochem 22: 401-408

Ulluwishewa D, Anderson RC, McNabb WC, Moughan PJ, Wells JM, Roy NC (2011) Regulation of tight junction permeability by intestinal bacteria and dietary components. J Nutr 141: 769-776

Wullaert A, Bonnet MC, Pasparakis M (2011) NF-êB in the regulation of epithelial homeostasis and inflammation. Cell Res 21: 146-158

Wu SJ, Don TM, Lin CW, Mi FL (2014) Delivery of berberine using chitosan/fucoidan-taurine conjugate nanoparticles for treatment of defective intestinal epithelial tight junction barrier. Mar Drugs 12: 56775697

Yang WK, Jung CS, Jung KW, Km JW, Lee EB (1992) Antigastritic and antiulcerative action of the extract of Zingiberis Rhizoma. J Pharm Soc Korea 36: 173-179 